\title{
Analysis of Pollen Collected by Andrena flavipes Panzer (Hymenoptera: Andrenidae) in Sweet Cherry Orchards, Afyonkarahisar Province of Turkey
}

\author{
Yasemin Güler ${ }^{1}$ and Kadriye Sorkun ${ }^{2}$ \\ ${ }^{1}$ Plant Protection Central Research Institute, Gayret Mahallesi, Fatih Sultan Mehmet Bulvari, \\ No: 66, 06172 Yenimahalle/Ankara, Turkey \\ ${ }^{2}$ Department of Biology, Faculty of Science, Hacettepe University, 06800 Beytepe/Ankara, Turkey
}

Correspondence should be addressed to Yasemin Güler, yaseminguler@gmail.com

Received 29 July 2009; Revised 4 December 2009; Accepted 7 January 2010

Academic Editor: James C. Nieh

Copyright ( $) 2010$ Y. Güler and K. Sorkun. This is an open access article distributed under the Creative Commons Attribution License, which permits unrestricted use, distribution, and reproduction in any medium, provided the original work is properly cited.

\begin{abstract}
Andrena, which is the largest genus in the Andrenidae, is a very important genus for the pollination of fruit trees. Andrena flavipes Panzer is one of the most common species observed in the study area and can continue the flight activity even under low temperature. In this study, the pollen collected by A. flavipes was determined. In addition, the potential to carry sweet cherry pollen of the aforementioned species was also researched. For the pollen preparates, the scopae of 34 females were used. As a result of the diagnosis studies, it was determined that A. flavipes species collected the pollens of 13 families and that the dominant pollen group belonged to the Brassicaceae. It was ascertained that A. flavipes collected sweet cherry pollen and that the sweet cherry flowers do not represent a primary pollen source, however.
\end{abstract}

\section{Introduction}

Sweet cherry (Prunus avium (L.) Moench) is the earliest ripening species among temperate climate fruit species. In about the current 1500 sweet cherry varieties throughout the world, except a few (such as the Stella) that are generated by artificial mutation, all are self-incompatible [1]. High fruit-set can only be accomplished through cross-pollination among the compatible varieties $[2,3]$. Henceforth, sweet cherry orchards require a huge population of pollinator bees that would carry out the adequate amount of pollen transfer between the different varieties [4]. In practice, the honeybee is the main pollinator used in sweet cherry orchards, due to reasons like its colony's purchase at relatively lower prices, breeding in easier conditions, and having many members that collect food in a colony [2] compared to the commercially managed other pollinators. However, sweet cherry's budding in very early periods, the negative effect of rain during the blooming period, and low temperatures limit the pollinator activities of honeybees $[5,6]$. In addition, pests and diseases of honeybees, natural competition between the bees that are natural inhabitants and brought later, loss of the habitat, invasive plant species spreading and pressuring the nectar and pollen producing vegetation, the reduction in honeybee genetic variety, and colony losses seen due to the chemicals used in cultivated areas form the main problems of beekeeping [7]. In this case, it is clear that a more diverse pollination strategy would be beneficial to longterm sustainability of crops that require insect pollinators. For this reason, the first step is to determine the presence of the wild bees in agroecosystems. Then, their floral resources and nesting habitat should be identified in order to protect them and increase their quantity [8].

In Turkey, there are two important activities related to bee-keeping. One of these is honeybee breeding that is especially made for bee products, and the other is the Bombus bee that is used to perform pollination operations (cross-fertilization) in the greenhouses. However, Özbek [9] indicates that there are about 2000 species of bee operating as pollinators in Turkey, which is one of the richest regions 
of the world in terms of bee fauna. Diagnosis of the pollen samples gathered by wild pollinators in agricultural ecosystems, particularly in extreme climatic conditions contributes to understand clearly whether or not there is a relationship between pollinators and products. On the other hand, understanding the roles of pollinator species in the ecosystem will facilitate to adopt pollinator friendly practices (foraging habitat, nesting areas, monitoring, etc.) that make it possible for them to survive in agricultural ecosystems. Therefore, it is mandatory to undertake researches on the species of bees to evaluate their current potential.

Andrena Fabricius is the most common genus of Andrenidae family within the Holarctic [10]. Although different levels of social organisation from solitary to presocial in Andrenidae have been detected [11], Andrena species are solitary bees [12]. These species are also called "mining bees" as they nest in the soil [13]. Klug and Bünemann [14] state that Andrena species are very effective for the pollination of fruit trees. A. flavipes which is one of the most common species of Andrena genus is bivoltine. Spring generation displays activity between March and May, whereas summer generation between July and September. It is known that the species is polylectic species as it feeds on the pollens of Apiaceae, Asteraceae, Brassicaceae, Lamiaceae, Fabaceae, and other families [15]. Furthermore, it is found that it is dominant species in some of the agricultural ecosystems such as apple orchards [16], alfalfa [17, 18], and onion fields [19].

In this study, it was aimed to identify the pollen collected of A. flavipes Panzer, which is considered as potential pollinators of fruit trees, in the sweet cherry orchards. The reason for selecting A. flavipes for the current study is that it is one of the most abundant species during the blooming period of the sweet cherry orchards and that it can fly even though the temperature is under $12^{\circ} \mathrm{C}$. Vicens and Bosch [20] also state that some early-flying bees including the species of Andrena are known to forage on Prunus flowers when weather conditions are unfavorable for honeybees. Thus, whether or not it would be an important pollinator for sweet cherry flowers was tried to be determined. The study was undertaken in the sweet cherry orchards in Sultandağ 1 town (Afyonkarahisar). This town is in fourth place in Turkey's sweet cherry production with 18,434 tons [21] per year [22].

\section{Materials and Methods}

2.1. Study Area. This study was undertaken in the sweet cherry orchards in Sultandağ 1 town located in the east of Afyonkarahisar, Turkey. Bee samples were collected by Malaise trap from two sweet cherry orchards in the period between 15 March-15 May in 2007 and 2008. There were 300 sweet cherry trees in the first and 700 in the second orchard, of 0900 Ziraat sweet cherry variety which were produced to be exported. Bing and Stella cultivars were used as pollenizers. The traps were set in the bud swell period and lifted in the green fruit period. Samples collected in the killing bottle were killed by ethyl acetate.
The diagnosis of Andrena flavipes Panzer species was carried out by Dr. Tomozei (Museum of Natural Sciences "Ion Borcea" Bacău, Romania).

2.2. Pollen Analysis. For the pollen preparates; among the collected female A. flavipes, 34 samples that had pollens in the scopa were used. The pollen preparation was made following Güler and Sorkun [23]. In order to separate pollen from the scopa, third pair of legs was placed inside $25 \mathrm{~mL}$ glass tubes. Five $\mathrm{ml}$ of $70 \%$ alcohol were added to the tubes and mixed by glass baget for 15 minutes. The contents were filtered into clean tubes using wire filter of $250 \mu \mathrm{m}$ pore size. The sample tubes were centrifuged at $3500 \mathrm{rpm}$ for 30 minutes. The supernatant was decanted and $5 \mathrm{~mL}$ distilled water was added to the pollen pellet. The tubes were centrifuged at $3500 \mathrm{rpm}$ for 15 minutes. The supernatant was decanted and the tube caps were left open on the benchtop for 10 minutes for the pellet to dry.

Basic fucsin-glycerin-gelatine mixture taken with the edge of a sterile needle was added to the pollen pellet. The stained sample was transferred to a microscope slide and put on a hotplate set at $40^{\circ} \mathrm{C}$. When the gelatine was melted, $18 \times 18 \mathrm{~mm}$ cover slips were placed on the samples. The analysis was carried out through the use of a Nikon Eclipse E400 microscope. Diagnosis was carried out following the related literature [24-29]. In order to verify the diagnosis, reference microscope slides prepared from pollens of formerly diagnosed plant species were used. Two hundred of pollen grains were counted in each slide and percentage of pollen was calculated according to taxa. Those percentages were used to determine abundant of taxa. The following terms were used for frequency classes: dominant pollen (more than $20 \%$ of pollen grains counted), secondary pollen $(11-20 \%)$, minor pollen $(6-10 \%)$ and rare pollen (less than 5\%) [30-33].

In addition, throughout the study in the orchards, the plants that were in the blooming period were collected and pressed and transformed into herbarium material. The diagnosis of this material was carried out by Dr. Mutlu (Inönü University, Malatya).

\section{Results and Discussion}

Pollen diagnosis were able to be made on a genus level, all of the pollen samples which could not be diagnosed down to this level were collected and evaluated under their associated family's names as well. While pollens belonging to 21 families were diagnosed as a result of the study, pollens belonging to families of the Campanulaceae, Geraniaceae, Lamiaceae, Oleaceae, Papaveraceae, Plantaginaceae, Salicaceae and Zygophyllaceae were only seen in singly preparates, and their amounts in these preparates again did not exceed one or two. Thus, pollens belonging to these families were accepted as accidental infection and were left out of evaluation. As a result of the diagnosis of the plant samples that were collected in orchards and transformed into herbarium material; the species of Capsella bursa-pastoris (L.) Medik., Barbarea vulgaris R. Br., Senecio 


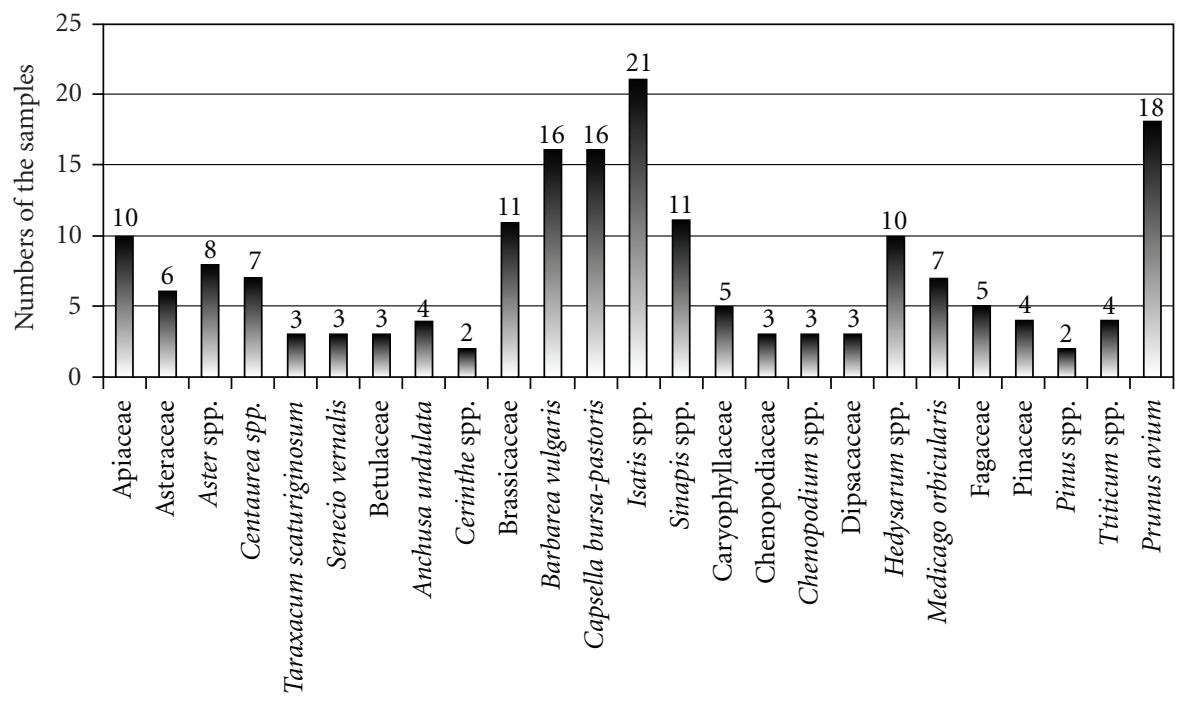

FIgURE 1: The plants that A. flavipes collected pollen.

vernalis Waldst. \& Kit., Taraxacum scaturiginosum G. Hagl., Anchusa undulata L. and Medicago orbicularis (L.) Bart. were identified. In addition; as the samples associated with the Prunus genus were the only species that were blossomed at the time of the study, Prunus spp. was taken into evaluation as P. avium (L.) Moench (sweet cherry). Other genera identified in the pollen preparates were not diagnosed on a species level as they were not present in the plant species collected in the orchards. It is thought that these pollen samples were collected by the bees in the areas surrounding the sweet cherry orchards. Because it is known that A. flavipes generally went $120-150 \mathrm{~m}$ away from their nests in order to nourish, and flied maximum $415 \mathrm{~m}$ away [34].

Other identified families and genera and species associated with these families are shown in Table 1

In the samples taken into evaluation, those pollens belonging to the Brassicaceae family were the commonest ones $(40.11 \%)$. This finding supports the assumption of Tadauchi [35] that regards A. flavipes as the most significant pollinator for Brassica in spring in Kazakhstan and Kyrgyzstan. In addition, the dominant pollen in every preparate again belonged to this family as well. Within the Brassicaceae; among the Isatis, Barbarea, Capsella and the Sinapis spp., the pollen of Isatis spp. was the most preferred by A. flavipes (Figure 1). This genus's pollen production is secondary, and nectar production is at minor level. While Capsella bursapastoris that is one of its second preferred species does not have too much importance in terms of bee-keeping, both pollen and nectar production of the other species (Barbarea vulgaris) are at secondary level. On the other hand, the pollen production of Sinapis spp. is minor and nectar production is secondary [36].

The families identified outside the Brassicaceae, especially the Asteraceae and Rosaceae, were found in many bee samples. Asteraceae is the family with the highest number of species within Turkey [37, 38]. D'Albore [29] has formed a grading system in which he rated the species of plants between 1 (being the rare) and 4 (being the
TABLE 1

(1) Apiaceae

(2) Asteraceae

Aster spp.

Centaurea spp.

Senecio vernalis Waldst. \& Kit.

Taraxacum scaturiginosum G. Hagl.

(3) Betulaceae

(4) Boraginaceae

Anchusa undulata L.

Cerinthe spp.

(5) Brassicaceae

Barbarea vulgaris $\mathrm{R}$. Br.

Capsella bursa-pastoris (L.) Medik.

Isatis spp.

Sinapis spp.

(6) Caryophyllaceae

(7) Chenepodiaceae Chenopodium spp.

(8) Dipsacaceae

(9) Fabaceae

Hedysarum spp.

Medicago orbicularis (L.) Bart.

(10) Fagaceae

(11) Pinaceae Pinus spp.

(12) Poaceae Triticum spp.

(13) Rosaceae Prunus avium (L.) Moench

dominant) according to their pollen and nectar production for honeybees. In this system, the species of Centaurea scored 3 and 4 for pollen and nectar productivity, whereas the scores 
for Aster were 2 and 1, respectively. The species of Taraxacum are the earliest blooming species in the spring. In addition, it is dominant in terms of both pollen and nectar production [36].

Weeds in the orchards function as alternative food resources for the bees in the environment, prior to the blooming of sweet cherry. As a matter of fact, Bosch et al. [4] determined that populations of Osmia lignaria (Hymenoptera: Megachilidae), which they released to the sweet cherry orchard where blooming delayed due to bad climatic conditions, survived feeding on Taraxacum sp. that was present in the orchard. While the Rosaceae family was represented by a single species ( $P$. avium) in the orchards at the time the study was undertaken, other families had more species in the blooming period. Although pollen and nectar production of $P$. avium are on minor levels, it was found $P$. avium pollens in 18 of the 34 bee samples (Figure 1). The results of the pollen analysis indicate that the sweet cherry flowers do not represent a primary pollen source. However, A. flavipes seems to play an important role in cherry orchards particularly when the populations of honey bees are insufficient or when there is low temperature conditions.

\section{Acknowledgments}

The authors would like to thank Dr. Bogdan Tomozei (Museum of Natural Sciences "Ion Borcea” Bacău, Romania) for the diagnosis of Andrena flavipes, and Dr. Birol Mutlu (İnönü University, Malatya) for the diagnosis of herbarium materials in the manuscript. The research was financially supported by the General Directorate of Agricultural Research, Ministry of Agriculture and Rural Affairs.

\section{References}

[1] M. Burak, Meyvecilik 1, Tarım ve Köyişleri Bakanlı̆̆ı Teşkilatlanma ve Desteklenme Genel Müdürlü̆̆̈̈, Baskı, Yayçep, 2 edition, 2003.

[2] K. S. Delaplane, Crop Pollination by Bees, CABI Publishing, Cambridge, Mass, USA, 2000.

[3] J. Bosch and W. P. Kemp, "Exceptional cherry production in an orchard pollinated with blue orchard bees," Bee World, vol. 80, no. 4, pp. 163-173, 1999.

[4] J. Bosch, W. P. Kemp, and S. S. Peterson, "Management of Osmia lignaria (Hymenoptera: Megachilidae) populations for almond pollination: methods to advance bee emergence," Environmental Entomology, vol. 25, no. 5, pp. 874-883, 2000.

[5] A. Roversi, V. Ughini, et al., "Influence of weather conditions of the flowering period on sweet cherry fruit set," in Proceedings of the International Cherry Symposium, pp. 427-433, Budapest, Hungary, June 1993, Acta-Horticulturae, no. 410.

[6] Z. Huang, "The other bees: alternative pollinators for tree and small Fruits," Fruit Crop Advisory Team Alert, Michigan State University, vol. 18, no. 6, 2003.

[7] I. Kandemir, "Amerika Birleşik Devletleri'nde toplu arı ölümleri ve koloni çökme bozukluğu (Ccd) üzerine bir derleme," Uludağ Arıcılık Dergisi, vol. 2, pp. 63-69, 2007.

[8] J. Tuell, J. A. Ascher, and R. Isaacs, "Wild bees (Hymenoptera: Apoidea: Anthophila) of the Michigan highbush blueberry agroecosystem," Annals of the Entomological Society of America, vol. 102, no. 2, pp. 275-287, 2009.

[9] H. Özbek, "Korunga (Onobrychis sativa Lam.) tohum üretiminde arıların yeri," in Türkiye 3. Çayır, Mer'a ve Yem Bitkileri Kong, pp. 429-434, Erzurum, Turkey, 1996.

[10] C. D. Michener, The Bees of the World, The Johns Hopkins Universitiy Press, Baltimor, Md, USA, 2000.

[11] M. Giovanetti, S. Luppino, and R. Zola, "Preliminary note on the relative frequencies of two bees on wild Brassicaceae: oligolectic Andrena agilissima vs polylectic Apis mellifera," Bulletin of Insectology, vol. 59, no. 2, pp. 153-156, 2006.

[12] A. Dubitzky, "New palearctic species of the bee genus Andrena (Insecta: Hymenoptera: Andrenidae)," Zootaxa, no. 1284, pp. 1-27, 2006.

[13] H. Özbek, “Türkiye'de iliman iklim meyve türlerini ziyaret eden böcek türleri," Uludă̆ Arıcılık Dergisi, vol. 8, no. 3, pp. 92-103, 2008.

[14] M. Klug and G. Büneman, "Pollination: wild bees as an alternative to the honey bee," Acta Horticulturae, vol. 139, pp. 59-64, 1983.

[15] P. Zandigiacomo, I. Bernardinelli, and M. Mossenta, "Fenology and plant preference of three species of wild bees (Hymenoptera, Apoidea) in Friuli-Venezia Giulia," in Proceedings of the 1st European Conference of Apidology, Udine, Italy, September 2004.

[16] H. Özbek, "Doğu Anadolu'nun baz1 yörelerinde elma ağaçlar1nda tozlaşa yapan ar1lar (Hymenoptera: Apoidea)," Atatürk Üniversitesi Ziraat Fakültesi Ziraat Dergisi, vol. 9, no. 4, pp. 73-83, 1978.

[17] M. I. Voloshin, "Principal pollinators of alfalfa in South Russia," in Proceedings of the 38th North American Alfalfa Improvement Conference, Sacramento, Calif, USA, July 2002.

[18] V. A. Vereshchagina, L. V. Novoselova, and N. L. Kolyasnikova, "The systems of reproduction of annual and perennial species of Medicago L. (Fabaceae," Czech Journal of Genetics and Plant Breeding, vol. 39, pp. 100-103, 2003.

[19] L. Tanács, P. Benedek, T. Monostori, and K. Bodnár, "Pollinating insect assemblages of seed onion fields at the traditional onion growing area of Makó," Symposium of Trends in European Agriculture Development, Timişoara, Serbia, vol. 40, no. 1, pp. 515-520, 2008.

[20] N. Vicens and J. Bosch, "Weather-dependent pollinator activity in an apple orchard, with special reference to Osmia cornuta and Apis mellifera (Hymenoptera: Megachilidae and Apidae)," Environmental Entomology, vol. 29, no. 3, pp. 413-420, 2000.

[21] Anonymous, Tarımsal Yapı (Üretim, Fiyat, Değer), Yayın no: 3123, T.C. Başbakanl $\imath \mathrm{k}$ Devlet Istatistik Enstitüsü, Ankara,Turkey, 2006.

[22] N. Çakaryıldırım, “Kiraz,” Bak1ş, Tarımsal Ekonomi Araştırma Enstitüsü, vol. 3, no. 12, pp. 1-4, 2003.

[23] Y. Güler and K. Sorkun, "Pollen preferences of Hoplosmia bidentata and Lithurgus cornutus (Hymenoptera: Megachilidae)," Entomologica Fennica, vol. 18, no. 3, pp. 174-178, 2007.

[24] G. Erdtman, Handbook of Palynology, Hafner, New York, NY, USA, 1969.

[25] V. Markgraf and H. L. D’Antoni, Pollen Flora of Argentina, The University of Arizona Press, Tucson, Ariz, USA, 1978.

[26] P. D. Moore, J. A. Webb, and M. E. Collinson, Pollen Analysis, Blackwell Scientific, London, UK, 1991.

[27] S. Nilsson, J. Praglowski, and L. Nilsson, Atlas of Airborne Pollen Grains and Spores in Northern Europe, Natur och Kultur, Stockholm, Sweden, 1983. 
[28] K. Faegri and J. Iversen, "Textbook of pollen analysis," K. Faegri, P. E. Kaland, and K. Krzywinski, Eds., p. 328, John Wiley \& Sons, Chichester, UK, 4th edition, 1989.

[29] G. R. D'Albore, Textbook of Melissopalynology, Apimondia Publishing House, Bucharest, Romania, 1997.

[30] M. H. Lieux, "A melissopalynological study of 54 Louisiana (USA) honeys," Review of Palaeobotany and Palynology, vol. 13, no. 2, pp. 95-124, 1972.

[31] S. Silici, "Physicochemical and palynological analysis of honey samples belonging to different regions of Turkey," Mellifera, vol. 4, no. 7, pp. 44-50, 2004.

[32] N. Erdoğan, S. Pehlivan, and C. Doğan, "Pollen analysis of honeys from Hendek- Akyazı and Kocaeli districts of Adapazarı province (Turkey)," Mellifera, vol. 6, no. 10-12, pp. 20-27, 2006.

[33] C. Doğan, "Physicochemical characteristics and composition of Trifolium L. honeys produced in turkey," Mellifera, vol. 8, no. 16, pp. 9-18, 2008.

[34] A. Gathmann and T. Tscharntke, "Foraging ranges of solitary bees," Journal of Animal Ecology, vol. 71, no. 5, pp. 757-764, 2002.

[35] O. Tadauchi, "The genus Andrena from Kazakhstan and Kyrgyzstan (Hymenoptera, Andrenidae) (2)," Esakia, vol. 48, pp. 1-18, 2008.

[36] K. Sorkun, Türkiye’in Nektarlı Bitkileri, Polenleri ve Balları, Palme Yayınevi, Ankara, Turkey, 2007.

[37] P. H. Davis, Ed., Flora of Turkey and the East Aegean Island, vol. 5, Edinburgh University Press, Edinburgh, UK, 1975.

[38] A. Güner, N. Özhatay, T. Ekim, and K. H. C. Başer, Flora of Turkey and the East Aegean Islands, vol. 11, supplement-II, Edinburgh University Press, Edinburgh, UK, 2000. 

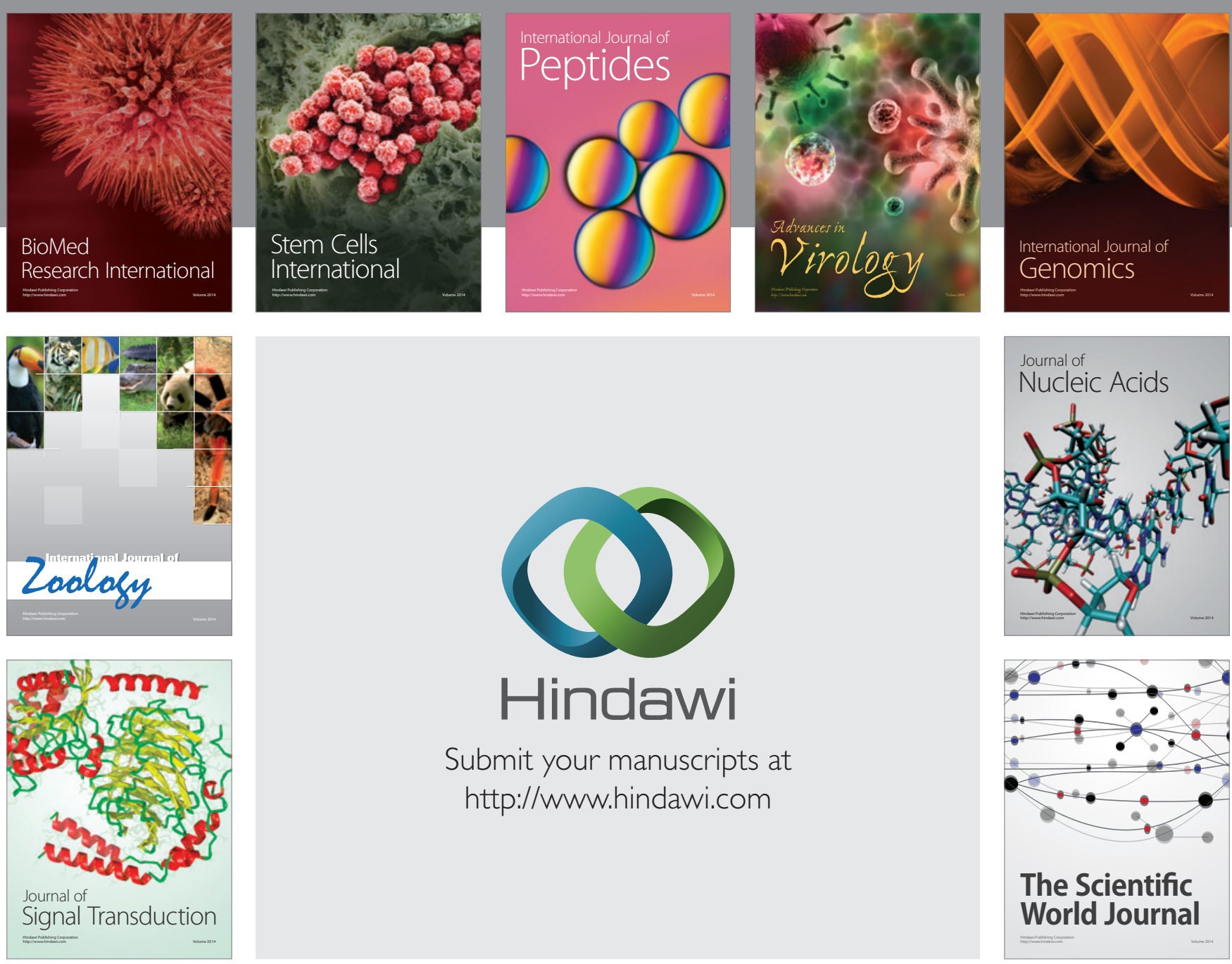

Submit your manuscripts at

http://www.hindawi.com
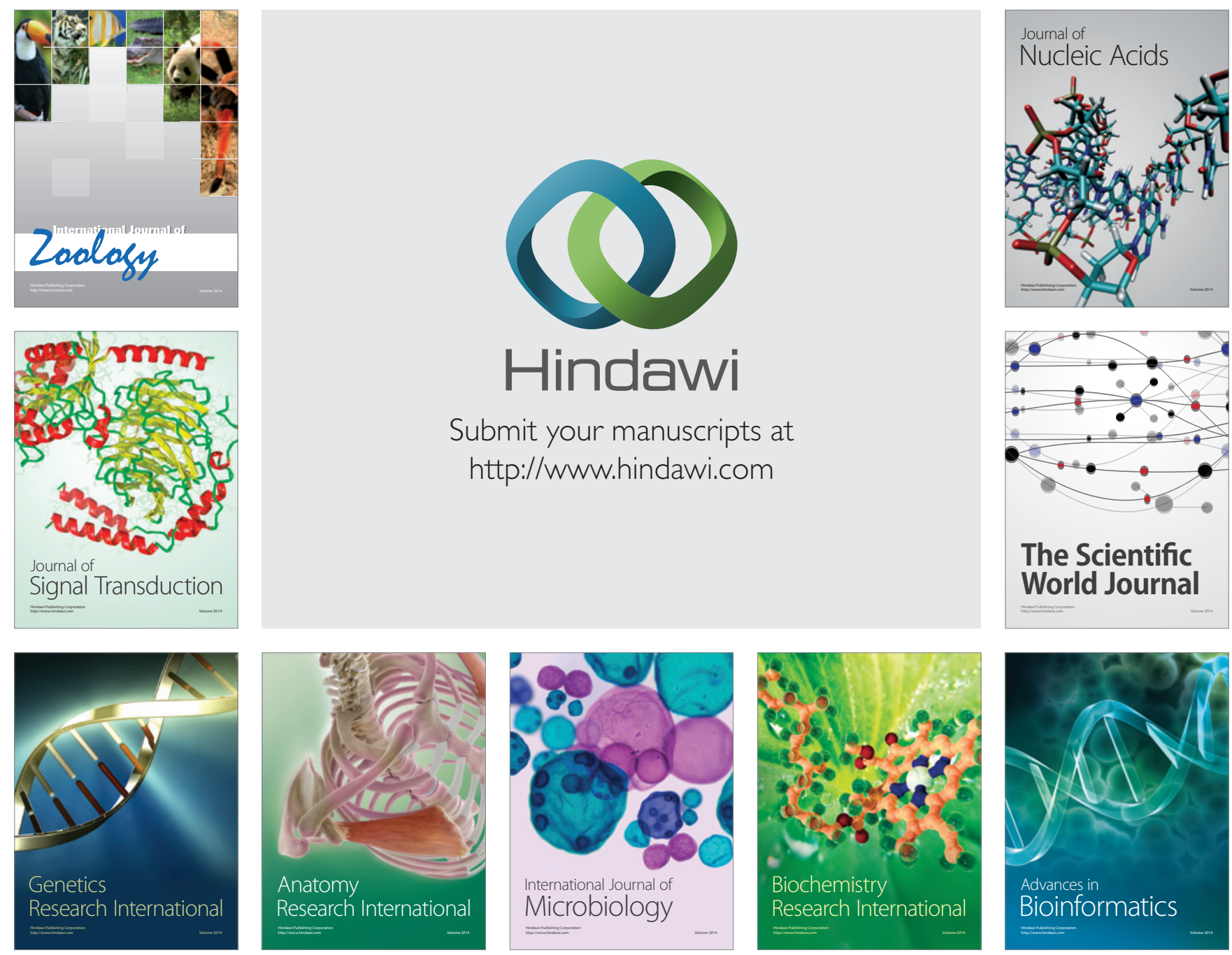

The Scientific World Journal
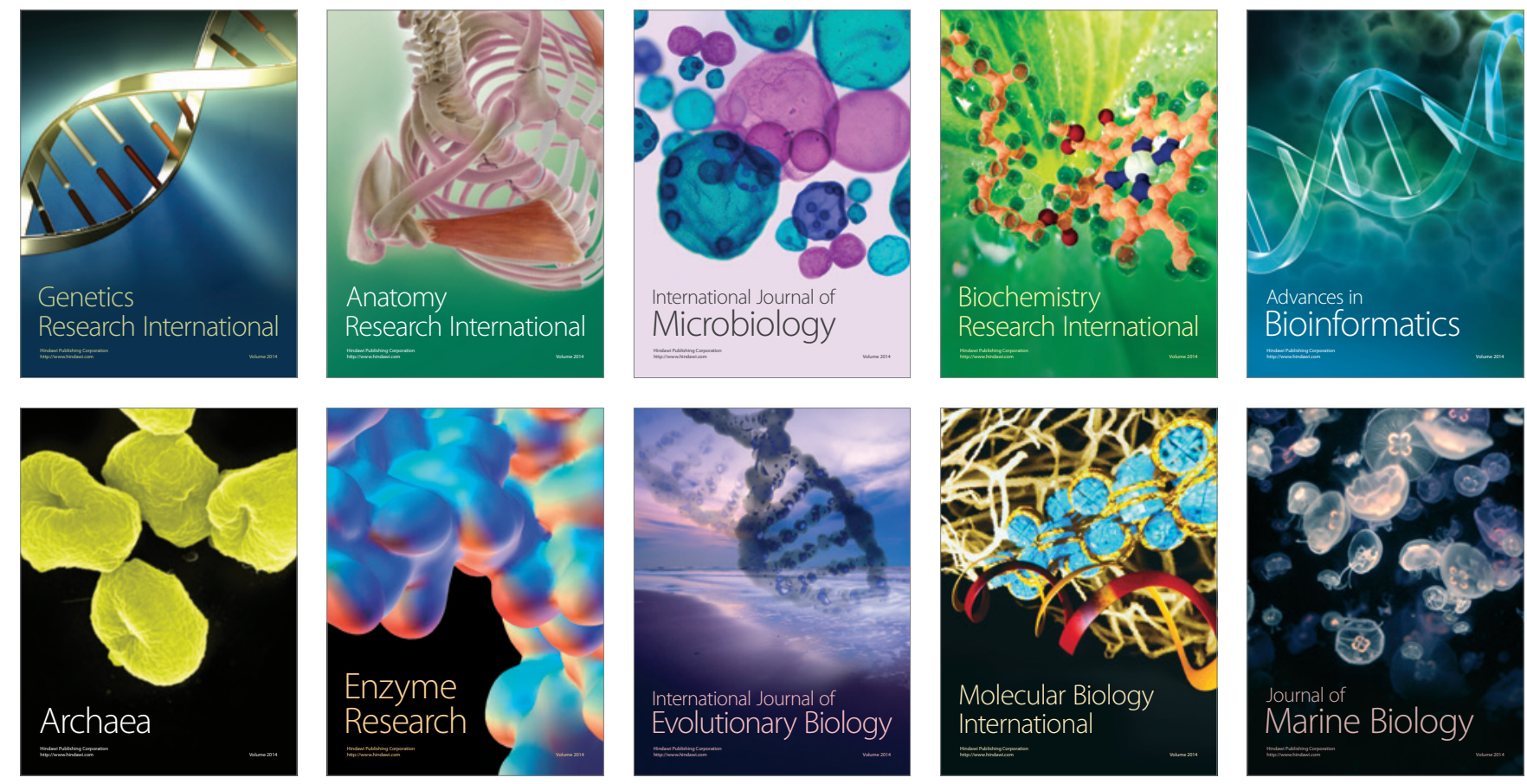